\title{
THE EFFECT OF PHYTOGENIC ADDITIVE ON BEHAVIOR DURING MILD - MODERATE HEAT STRESS IN BROILERS
}

\author{
Vladimír Zmrhal ${ }^{1}$, Martina Lichovníková ${ }^{1}$, David Hampel ${ }^{2}$
}

\begin{abstract}
${ }^{1}$ Department of Animal Breeding, Faculty of Agrisciences, Mendel University in Brno, Zemedelska 1, 61300 Brno, Czech Republic

${ }^{2}$ Department of Statistics and Operation Analysis, Faculty of Business and Economics, Mendel University in Brno, Zemedelska 1, 613 00, Brno, Czech Republic
\end{abstract}

\begin{abstract}
ZMRHAL VLADIMÍR, LICHOVNÍKOVÁ MARTINA, HAMPEL DAVID. 2018. The Effect of Phytogenic Additive on Behavior During Mild-Moderate Heat Stress in Broilers. Acta Universitatis Agriculturae et Silviculturae Mendelianae Brunensis, 66(4): 939-944.

The aim of this study was to evaluate the effect of phytogenic additive with anti-inflammatory and antioxidant properties on thermoregulatory behavior (lifting of the wings, high respiratory rate defined as open beaks) and water and feed intake in mild-moderate heat stressed Cobb 500 broiler chickens. From $28^{\text {th }}$ day of chickens' age experimental group was supplemented with $0.1 \%$ phytogenic additive based on Scutellaria baicalensis L. extract in the diet. At the age 30 days temperature was increased to $27^{\circ} \mathrm{C}$ and kept the same till the end of experiment at 34 days of age. Ethological observation was performed $31^{\text {st }}, 32^{\text {nd }}$ and $33^{\text {th }}$ days of experiment. Monitoring was performed in three observation periods at the start, in the middle and at the end of 18h day length, always for three consecutive hours. Changes in chickens' behavior among days and observation periods, as well as the influence of phytogenic additive were evaluated. Manifestations of thermoregulatory behavior were significantly higher $(\mathrm{p}<0.001)$ in the middle and at the end of photoperiod. Significantly the highest number of chickens fed diets $(\mathrm{p}<0.001)$ at the end of day-light, water intake was the lowest in the middle of the day $(p<0.001)$. Significantly the oftenest lifting of the wings $(p<0.001)$, high respiratory rate $(p<0.001)$ and feed intake $(p=0.017)$ were found in 33 days of chickens' age. Feeding of phytogenic additive did not affect water intake and feed intake, anyway significantly reduced ( $\mathrm{p}<0.001$ ) thermoregulatory behavior.
\end{abstract}

Keywords: thermoregulatory behavior, feed intake, water intake, Scutellaria baicalensis L.

\section{INTRODUCTION}

Heat stress is the one of the most important stressor on broilers' farms. The importance of this stressor is in large numbers of negative impacts. Detrimental effect on performance parameters represented by decrease in body weight gain, feed intake and feed conversion ratio are well known (Quinteiro-Filho et al., 2010). Heat stress can also impairs meat quality; it significantly increases lactate production in meat and reduce its $\mathrm{pH}$ value by accelerating meat glycolysis (Zhang et al., 2012). Immune response of birds was also negatively affected. Heat stress cause decrease in relative weight of lymphoid organs (Niu et al., 2009). There is also a reduction in lymphocyte blood concentration (Altan et al., 2000). Higher ambient temperature has effect on corticosterone levels; increasing levels of corticosterone was found in broilers affected by high ambient temperatures (Sohail et al., 2012).

Under high temperature conditions the bird body attempts to maintain its thermal homeostasis. This is ensure mainly through thermoregulatory behavior such as panting, elevated wings and resting (Mack et al., 2013). The evaluation of 
behavior in high temperatures is helpful for detection of stress level in a flock.

There are several ways how to mitigate negative heat stress effects. Very useful is high air velocity from 4 to 6 weeks of age, which can improve performance of broilers in high temperatures (Simmons et al., 2003). Another approach to heat stress elimination is through nutrition. Dietary supplementation of ascorbic acid may alleviate negative effects of heat stress on performance parameters and meat quality (Toplu Oral et al., 2014). Detrimental effect of oxidative stress by producing free radicals may be reduced and subsequently immune response could be improved by vitamin $\mathrm{E}$ addition (Niu et al., 2009).

Nowadays, the use of various phytogenic additives is very actual. The beneficial influence on heat stress negative effects elimination have been demonstrated in the Scutellaria baicalensis L. Flavones such as baicalin and wogonoside and their aglycones baicalein and wogonin are the major bioactive compounds extracted from the roots of Scutellaria baicalensis L. These flavones have been reported to have various functions, including anti-cancer, hepatoprotective, antibacterial, antiviral, antioxidant and neuroprotective effects (Zhao et al., 2016). Furthermore, supplementation of Scutellaria baicalensis L. extract with curcuma extract may be used in broiler nutrition with the aim to effectively decrease gut inflammation induced by heat stress and consequently increase chicken performance (Varmuzova et al., 2015). Park et al. (2016) found a positive effect of Scutellaria baicalensis L. extract on broilers performance in high ambient temperatures too. Effects of some active compounds on nervous system, mainly their anxiolytic effect are also interesting from scientific point of view. This effect has been demonstrated in mice. Wogonin exhibited anxiolytic effect by mediation influencing GABAergic transmission in the brain (Navratilova and Patocka 2016). This effect can cause behavioral changes, mostly in stressful situations. The aim of this study was to evaluate the effect of phytogenic additive based on Scutellaria baicalensis L. extract on thermoregulatory behavior in broilers under persistent mild - moderate heat stress.

\section{MATERIALS AND METHODS}

\section{Animals and treatments}

Both sexes of 135 one day old broiler chickens Cobb 500 were housed in 12 littered floor boxes in one room, 10-12 per box, with controlled environmental conditions.

Temperature in the room was $30^{\circ} \mathrm{C}$ at the start of experiment and gradually decreased to $20^{\circ} \mathrm{C}$ according to guidelines for the hybrid. The light regime was as follow: in the first week of experiment 23 hours of light and 1 hour of darkness and after the first week 18 hours of light and 6 hours of darkness were applied. The water intake was supplied with nipple drinkers and feeding was manually submitted from tube feeders. The water and feed were available ad libitum.

Chickens fed broiler diets meeting the nutrient requirements for Cobb 500.

Starter (crumble pellets) was fed from 1 to 10 days of chicken age, grower (pellets) from 10 to 28 days. All chickens fed the same diets starter and grower based on maize, wheat, soybean meal, rapeseed meal, calcium carbonate, calcium dihydrogen phosphate, animal fat and sodium chloride. Finisher (pellets) was fed from 28 days to 34 days. Composition of finisher was based on wheat, maize, soybean meal, soybeans, rapeseed meal, animal fat, calcium carbonate, sodium chloride, monocalcium phosphate and sodium sulfate. Content of nutrients in the diets is shown in the Tab. I. At the age 28d boxes were divided into two groups; control and experimental. Control group fed control diet finisher and experimental group fed the same diet finisher, which was only supplemented with $0.1 \%$ phytogenic additive Axion FEEDSTIM based on extract from Scutellaria baicalensis L. roots.

From 28 days of age temperature in the room had been increased up to 30 days of age and kept the same till the end of experiment, consequently chickens exposure to heat stress ran from $31^{\text {st }}$ to $34^{\text {th }}$ day. Temperature and humidity from $28^{\text {th }}$ day were as follow: $28 \mathrm{~d}: 21^{\circ} \mathrm{C}, 66 \%$; $31 \mathrm{~d}: 27^{\circ} \mathrm{C}$, $57.5 \%$; 32d: $27{ }^{\circ} \mathrm{C}, \quad 47.6 \%$; 33d: $27^{\circ} \mathrm{C}, \quad 44.5 \%$. Temperature-humidity index (THI) values were as

I: Content of nutrients in the diets

\begin{tabular}{lccc}
\hline \multicolumn{1}{c}{ Content of nutrients $\left[{\left.\mathrm{g} . \mathrm{kg}^{-1}\right]}^{-}\right.$} & Starter & Grower & Finisher \\
\hline Crude protein & 196 & 187.0 & 198 \\
Crude oil and fats & 40 & 48 & 85 \\
Crude fiber & 29 & 33 & 35 \\
Crude ash & 53 & 43 & 46 \\
Lysine & 11.7 & 10.9 & $11-8$ \\
Methionine & 4.9 & 4.7 & 3 \\
Calcium & 9 & 6.0 & 5.1 \\
Phosphorum & 5.5 & 4.4 & 4.4 \\
Sodium & 1.4 & 1.3 & 1.6 \\
\hline
\end{tabular}


follow: 28d: 66, 31d: 75-76, 32d: 74-75, 33d: 73-74 (Burgos-Zimbelman and Collier, 2011). THI values from 72 to 79 are considered as mild - moderate stress (Burgos Zimbelman and Collier, 2011).

\section{Ethological observation}

Ethological observations were performed 31, 32 and 33 days of chickens' age. Monitoring was performed at half-hour intervals during three consecutive hours in three observation periods in $18 \mathrm{~h}$ photoperiod. Lights switch on at $4 \mathrm{~h}$ and switch off at $22 \mathrm{~h}$ on each observation day. First observation period was conducted from $4 \mathrm{~h}$ to $7 \mathrm{~h}$, second observation period from $12 \mathrm{~h}$ to $15 \mathrm{~h}$ and third period was conducted from $19 \mathrm{~h}$ to $22 \mathrm{~h}$. In total 63 observations were realized. Observation was carried out by the same spotter. Behaviors were observed in all boxes by scan sampling method, which means that a group of individuals is quickly scanned at periodic intervals and the behavior of each member of this group is recorded immediately. The time spent watching each individual should be short and approximately constant (Martin and Bateson, 2007). Number of birds showing given behavior was expressed in percentage of total number of birds.

\section{Description of behavioral manifestations}

High respiratory rate was defined as open beaks. Next observed thermoregulatory behavior was lifting of the wings: a space can be seen between broiler wings and body (thus more air is moved between body and wing). Feed intake, when broiler head is located inside tube feeder and water intake, when broiler beak is in contact with a nipple drinker were included too.

\section{Statistical analysis}

Observed data can be seen as binomial proportions, so generalized linear model with logit link was employed to evaluate statistical significance of factors phytogenetics additive, age and day-light phase. Predictions of factor levels were calculated for significant factors and distinguish levels were found based on the least significance differences. Significance level was set to 0.05 . All calculations were provided in the computational system Genstat 17.

\section{RESULTS}

The effects of broiler chickens age (31, 32 and 33d), day-light phase (morning, midday, evening) and phytogenic additive on chosen broiler behavior were estimated. Behavioral changes depending on day-light phase are shown in Tab. II. Tab. III shows broilers behavior in $31^{\text {st }}, 32^{\text {nd }}$ and $33^{\text {th }}$ day of fattening. The effect of phytogenic additive on behavior of heat stressed broilers is shown in Tab. IV.

\section{Beak opening}

Open beaks and accelerated breath are main symptoms of heat stress. All three factors had significant effect on this behavior. Significantly highest numbers of birds $(p<0.001)$ with an open beak were between 12:00 and 15:00 and in $33^{\text {th }}$ day of fattening. On the other hand, lowest numbers of this behavioral manifestation were observed between $4: 00$ and $7: 00$. In $31^{\text {st }}$ and $32^{\text {nd }}$ days a number of birds with open beaks was almost the same. Feeding of phytogenic additive significantly decreased manifestation of this behavior $(p<0.001)$.

II: Behavior of broilers exposed mild-moderate heat stress depending on day-light phase [\%]

\begin{tabular}{lcccc}
\hline \multicolumn{1}{c}{ Day-light phase } & Open beaks & Wings lifting & Feed intake & Water intake \\
\hline $\mathbf{4 h - 7 h}$ & $46.8^{\mathrm{a}}$ & $58.8^{\mathrm{a}}$ & $6.9^{\mathrm{b}}$ & $11.6^{\mathrm{b}}$ \\
$\mathbf{1 2 h - 1 5 h}$ & $62.6^{\mathrm{c}}$ & $74.1^{\mathrm{b}}$ & $6.2^{\mathrm{a}}$ & $7.7^{\mathrm{a}}$ \\
$\mathbf{1 9 h - 2 2 h}$ & $57.7^{\mathrm{b}}$ & $74.7^{\mathrm{b}}$ & $9.8^{\mathrm{c}}$ & $10.1^{\mathrm{b}}$ \\
\hline
\end{tabular}

a, b, c-statistically significant differences within columns

III: Behavior of broilers exposed mild-moderate heat stress depending on age [\%]

\begin{tabular}{lcccc}
\hline \multicolumn{1}{c}{ Broilers age } & Open beaks & Wings lifting & Feed intake & Water intake \\
\hline $\mathbf{3 1}^{\text {st }}$ day & $54.5^{\mathrm{a}}$ & $53.6^{\mathrm{a}}$ & $6.5^{\mathrm{a}}$ & $9.4^{\mathrm{ab}}$ \\
$\mathbf{3 2}^{\text {nd }}$ day & $53.9^{\mathrm{a}}$ & $73.7^{\mathrm{b}}$ & $8.0^{\mathrm{b}}$ & $11.3^{\mathrm{b}}$ \\
$\mathbf{3 3}^{\text {th }}$ day & $58.6^{\mathrm{b}}$ & $80.3^{\mathrm{c}}$ & $8^{\mathrm{c}}$ & $8.4^{\mathrm{c}}$ \\
\hline
\end{tabular}

a, b, c-statistically significant differences within columns

IV: Effect of phytogenic additive on broilers behavior exposed mild-moderate heat stress [\%]

\begin{tabular}{lcccc}
\hline & Open beaks & Wings lifting & Feed intake & Water intake \\
\hline Experimental group & $47.1^{\mathrm{a}}$ & $64.5^{\mathrm{a}}$ & $7.7^{\mathrm{a}}$ & $9.3^{\mathrm{a}}$ \\
Control group & $64.2^{\mathrm{b}}$ & $73.8^{\mathrm{b}}$ & $7.9^{\mathrm{a}}$ & $10.3^{\mathrm{a}}$ \\
\hline
\end{tabular}

a, b - statistically significant differences within columns 


\section{Wings lifting}

Age, day-light phase and phytogenic additive had significant effect on the behavior. Between 12:00 and 15:00 and also between 19:00 and 22:00 significantly higher numbers of broilers $(p<0.001)$ with lifted wings were observed in comparison with hours from $4: 00$ to $7: 00$. The manifestations of this behavior have increased significantly $(p<0.001)$ with age of broilers. Feeding of phytogenic additive caused reduction of thermoregulatory behavior; in control group significantly higher numbers of broilers with lifting wings was found $(\mathrm{p}<0.001)$.

\section{Feed intake}

Only age and day-light phase had significant effect on feed intake. The consumption was significantly highest in the evening, between 19:00 and $22: 00(\mathrm{p}<0.001)$, conversely lowest feed intake was observed between $12: 00$ and $15: 00$. It is well known, that feed intake increase with age, which was confirmed in this study $(p=0.017)$. Addition of phytogenic additive had no effect on eating behavior.

\section{Water intake}

As in feed intake, also in water intake significant effect on this behavior was observed only of age and day-light phase. In the morning and in the evening significantly higher $(p<0.001)$ water intake was observed than in the midday. Lowest numbers of drinking birds was found in $33^{\text {th }}$ day and significantly highest numbers $(p=0.040)$ of drinking birds were in $32^{\text {nd }}$ day. On the other hand $33^{\text {th }}$ day there was the highest number of feeding birds. Phytogenic additive added to the diet did not affect drinking behavior.

Live body gain and live body weight were higher in experimental group, but the difference were no significant. Feed conversion ratio was better in experimental group, but there was no significant difference between the groups and feed intake was almost the same in both groups (Zmrhal et al., 2017).

\section{DISCUSSION}

Previous studies have reported that broilers exposed to high ambient temperatures spent more time with sitting or lying behavior. Beak opening and wing spreading occurred more frequently in the highest daily temperatures and especially in connection with the highest body surface temperature and the highest radiant heat load (De Queiroz et al., 2013). High temperature reduced feed intake and also protein and energy intake (Syafwan et al., 2012).

Mack et al. (2013) studied the effect of heat stress on behavior in two strains of laying hens. Percentage of Dekalb hens manifesting elevated wings and panting was about $70 \%$ and $77 \%$ respectively. This numbers are higher compared to this study, probably because mild-moderate heat stress was applied in this study compared to Mack et al. (2013) study, where hens were exposed to higher constant temperature $32.6^{\circ} \mathrm{C}$.

The effect of semi-arid equatorial environment on daily behavior of naked-neck broilers were studied by De Queiroz et al., (2013). Numbers of panting birds and birds with elevated wings increased with increasing air temperature, the highest percentage of thermoregulatory behavior was observed between $12 \mathrm{~h}$ and $15 \mathrm{~h}$ at temperatures around $34^{\circ} \mathrm{C}$. Percentage of wings spreading and beak opening in this period were $45.5 \%$ and $32.4 \%$ respectively. Lower numbers compared to this study could be attributed to the different hybrids usage, because naked neck broilers exhibit greater surface area for non-evaporative heat exchange under high atmospheric temperatures (Yahav et al., 1998).

Feed intake had increased depending on the age increase, but number of drinking birds was significantly lower at 33 days of age in comparison with 32 days of ages. Bruno et al., (2011) proved that heat stressed broilers had higher water consumption, but lower frequency of drinker visiting. Li et al. (2015) showed that drinking times and eating duration of broilers under persistent heat stress also gradually increased with the increasing weekly age.

There is no available study to investigate the effect of Scutellaria baicalensis L. on poultry behavior under heat stress. However, Mahmoud et al. (2015) studied the effects of dietary supplementation of green Brazilian propolis on behavioral changes of heat stressed broiler chickens. Broilers were exposed to $32{ }^{\circ} \mathrm{C}$ daily from $8 \mathrm{~h}$ to $17 \mathrm{~h}$ from 15 to 42 days of experiment. Their results indicated the effects of propolis to reduced thermoregulatory behavior, presented by reduction of panting behavior $(p<0.05)$. On the other hand, there were no significant effects on wing elevations and, also feeding and drinking behavior. Bozakova et al. (2017) examined the effects of zinc and ascorbic acid supplementation on behavior of laying hens in hot summer period. In the group with treatment less moving and aggressive behavior was observed $(\mathrm{p}<0.01)$, but more preening $(\mathrm{p}<0.05)$ and dustbathing $(\mathrm{p}<0.001)$ compared to the control group was found.

Results of this study show that phytogenic additive based on Scutellaria baicalensis L. extract reduced thermoregulatory behavior in broilers under persistent mild-moderate heat stress. The results could be attributed to the anxiolytic effect of some active compounds like wogonin, baicalin and baicalein which has been demonstrated in mice (Hui et al., 2002; Liao et al., 2003). Baicalein also has an antidepressant activity in rats. After administration, the level of dopamine in the hippocampus increased (Lee et al., 2013). Main active compounds extracted from Scutellaria baicalesis L. roots have various effects on nervous system and thus can affect behavior in heat stressed broilers. 


\section{CONCLUSION}

Lifting of the wings and high respiratory rate defined as open beaks of mild-moderate heat stressed broilers significantly decreased at feeding phytogenic additive based on Scutellaria baicalensis L. extract. The lowest incidence of these behaviors was observed in the morning. With age lifting of the wings significantly increased.

\section{Acknowledgements}

This paper was supported by the project of MENDELU, Faculty of AgriSciences IGA No. TP 7/2017: Analysis of performance and behaviour of farm animals in relation to ambient temperature variability and possibilities of elimination of its impact. The experiment was done thanks equipment financed by project OP VaVpI CZ.1.05/4.1.00/04.0135.

\section{REFERENCES}

ALTAN, Ö., ALTAN, A., ÇABUK, M. and BAYRAKTAR, H. 2000. Effects of heat stress on some blood parameters in broilers. Turkish journal of veterinary and animal sciences, 24(2): 145-148.

BOZAKOVA, N., GERZILOV, V. and SOTIROV, L. 2017. Ethological study of free-range hens with zinc and vitamin c supplemented diet. Bulgarian Journal of Agricultural Science, 23(2): 289-297.

BRUNO, L. D. G., MAIORKA, A., MACARI, M., FURLAN, R. L. and GIVISIEZ, P. 2011. Water intake behavior of broiler chickens exposed to heat stress and drinking from bell or and nipple drinkers. Revista Brasileira de Ciência Avícola, 13(2): 147-152.

BURGOS-ZIMBELMAN, R. and COLLIER, R. J. 2011. Feeding strategies for high-producing dairy cows during periods of elevated heat and humidity. In: Proceedings of Tri-State Dairy Nutrition Conference. Fort Wayne, 19-20 April, USA: Department of Animal Sciences, University of Arizona, pp. 111-126.

DE QUEIROZ, J. P. A. F., DE SOUZA, J. B. F., DE LIMA, H. F. F., DE OLIVEIRA COSTA, M. K., DE MACEDO COSTA, L. L. and DE ARRUDA, A. M. V. 2013. Daily variations in the thermoregulatory behaviors of naked neck broilers in an equatorial semi-arid environment. International Journal of Biometeorology, 58(6): 1259-1264.

HUI, K. M., HUEN, M. S. Y., WANG, H. Y., ZHENG, H., SIGEL, E., BAUR, R., REN, H., LI, Z. W., WONG, J. T. and XUE, H. 2002. Anxiolytic effect of wogonin, a benzodiazepine receptor ligand isolated from Scutellaria baicalensis Georgi. Biochemical Pharmacology, 64(9): 1415-1424.

LEE, B., SUR, B., PARK, J., KIM, S. H., KWON, S., YEOM, M., SHIM, I., LEE, H. and HAHM, D. H. 2013. Chronic administration of baicalein decreases depression-like behavior induced by repeated restraint stress in rats. The Korean Journal of Physiology $\%$ Pharmacology, 17(5): 393-403.

LI, M., WU, J. and CHEN, Z. 2015. Effects of Heat Stress on the Daily Behavior of Wenchang Chickens. Revista Brasileira de Ciência Avícola, 17(4): 559-566.

LIAO, J. F., HUNG, W. Y. and CHEN, CH. F. 2003. Anxiolytic-like effects of baicalein and baicalin in the Vogel conflict test in mice. European Journal of Pharmacology, 464(2-3): 141-146.

MACK, L. A., FELVER-GANT, J. N., DENNIS, R. L. and CHENG, H. W. 2013. Genetic variations alter production and behavioral responses following heat stress in 2 strains of laying hens. Poultry Science, 92(2): 285-294.

MAHMOUD, U. T., ABDEL-RAHMAN, M. A. M., DARWISH, M. H. A., APPLEGATE, T. J. and CHENG, H. W. 2015. Behavioral changes and feathering score in heat stressed broiler chickens fed diets containing different levels of propolis. Applied Animal Behaviour Science, 166: 98-105.

MARTIN, P. and BATESON, P. 2007. Measuring behaviour: an introductory guide. Cambridge: Cambridge University Press.

NAVRATILOVA, Z. and PATOCKA, J. 2016. Baikal skullcap (Scutellaria baicalensis Georgi) and its effects on the nervous system. [in Czech: Šišák bajkalský (Scutellaria baicalensis Georgi) a jeho účinky na nervový systém]. Psychiatrie. 20(3): 127-131.

NIU, Z. Y., LIU, F. Z., YAN, Q. L. and LI, W. C. 2009. Effects of different levels of vitamin E on growth performance and immune responses of broilers under heat stress. Poultry Science, 88(10): 2101-2107.

NIU, Z., LIU, F., YAN, Q. and LI, L. 2009. Effects of different levels of selenium on growth performance and immunocompetence of broilers under heat stress. Archives of Animal Nutrition, 63(1): 56-65.

PARK, J. H., PI, S. H. and KIM, I. H. 2016. Growth performance, blood profile, nutrient digestibility and meat quality of broilers fed on diets supplemented with Scutellaria baicalensis extract. European Poultry Science, 80(155): 1-10.

QUINTEIRO-FILHO, W. M., RIBEIRO, A., FERRAZ-DE-PAULA, V., PINHEIRO, M. L., SAKAI, M., SA, L. R. M., FERREIRA, A. J. P. and PALERMO-NETO, J. 2010. Heat stress impairs performance parameters, induces intestinal injury and decreases macrophage activity in broiler chickens. Poultry Science, 89(9): 1905-1914. 
SIMMONS, J., LOTT, B. and MILES, D. 2003. The effects of high-air velocity on broiler performance. Poultry Science, 82(2): 232-234.

SOHAIL, M. U., HUME, M. E., BYRD, J. A., NISBET, D. J., IJAZ, A., SOHAIL, A., SHABBIR, M. Z. and REHMAN, H. 2012. Effect of supplementation of prebiotic mannan-oligosaccharides and probiotic mixture on growth performance of broilers subjected to chronic heat stress. Poultry Science, 91(9): 2235-2240.

SYAFWAN, S., WERMINK, G. J., KWAKKEL, R. P. and VERSTEGEN, M. W. A. 2012. Dietary selfselection by broilers at normal and high temperature changes feed intake behavior, nutrient intake, and performance. Poultry Science, 91(3): 537-549.

TOPLU ORAL, H. H., KARAARSLAN, A., KAYA, S., YAGIN, M. and ORÇUN, O. 2014. Effects of heat conditioning and dietary ascorbic acid supplementation on growth performance, carcass and meat quality characteristics in heat-stressed broilers. Ankara Üniversitesi Veteriner Fakültesi Dergisi, 61(4): 295-302.

VARMUZOVA, K., MATULOVA, M.E., GERZOVA,L., CEJKOVA,D., GARDAN-SALMON,D., PANHELEUX, M., ROBERT, F., SISAK, F., HAVLICKOVA, H. and RYCHLIK, I. 2015. Curcuma and Scutellaria plant extracts protect chickens against inflammation and Salmonella Enteritidis infection. Poultry Science, 94(9): 2049-2058.

YAHAV, S., LUGER, D., CAHANER, A., DOTAN, M., RUSAL, M. and HURWITZ, S. 1998. Thermoregulation in naked neck chickens subjected to different ambient temperatures. British Poultry Science, 39(1): 133-138.

ZHANG, Z. Y., JIA, G. Q., ZUO, J. J., ZHANG, Y., LEI, J., REN, L. and FENG, D. Y. 2012. Effects of constant and cyclic heat stress on muscle metabolism and meat quality of broiler breast fillet and thigh meat. Poultry Science, 91(11): 2931-2937.

ZHAO, Q., CHEN, X. Y. and MARTIN, C. 2016. Scutellaria baicalensis, the golden herb from the garden of Chinese medicinal plants. Science Bulletin, 61(18): 1391-1398.

Vladimír Zmrhal: xzmrhall@node.mendelu.cz Martina Lichovníková: lichovmartina@gmail.com David Hampel: david.hampel.uso@mendelu.cz 